NBER WORKING PAPER SERIES

\title{
RMBI OR RMBR: IS THE RENMINBI DESTINED TO BECOME A GLOBAL OR REGIONAL CURRENCY?
}

Barry Eichengreen

Domenico Lombardi

Working Paper 21716

http://www.nber.org/papers/w21716

\author{
NATIONAL BUREAU OF ECONOMIC RESEARCH \\ 1050 Massachusetts Avenue \\ Cambridge, MA 02138 \\ November 2015
}

The authors acknowledge CIGI for supporting this project and Coby Hu for excellent research assistance. The views expressed herein are those of the authors and do not necessarily reflect the views of the National Bureau of Economic Research.

NBER working papers are circulated for discussion and comment purposes. They have not been peerreviewed or been subject to the review by the NBER Board of Directors that accompanies official NBER publications.

(C) 2015 by Barry Eichengreen and Domenico Lombardi. All rights reserved. Short sections of text, not to exceed two paragraphs, may be quoted without explicit permission provided that full credit, including $\odot$ notice, is given to the source. 
RMBI or RMBR: Is the Renminbi Destined to Become a Global or Regional Currency?

Barry Eichengreen and Domenico Lombardi

NBER Working Paper No. 21716

November 2015

JEL No. F0,F02

\begin{abstract}
$\underline{\text { ABSTRACT }}$
Previous studies have focused on when the renminbi will play a significant role as an international currency, but less attention has been paid to where. We fill this gap by contrasting two answers to the question. One is that the renminbi will assume the role of a global currency similar to the U.S. dollar. Supporters point to China's widely diversified trade and financial flows and to its institutional initiatives, not just in Asia but around the world. The other is that the renminbi will play a regional role in Asia equivalent to that of the euro in greater Europe. Proponents of this view argue that China has a natural advantage in leveraging regional supply chains and deepening its links with other Asian countries as well as in developing regional institutions. Asia, they argue on these grounds, will become the natural habitat for the renminbi.
\end{abstract}

\author{
Barry Eichengreen \\ Department of Economics \\ University of California, Berkeley \\ 549 Evans Hall 3880 \\ Berkeley, CA 94720-3880 \\ and NBER \\ eichengr@econ.Berkeley.edu \\ Domenico Lombardi \\ CIGI \\ 67 Erb St. W. \\ Walterloo, Canada \\ dlombardi@cigionline.org
}




\section{Introduction}

Although much has been written about when China's currency, the renminbi, will assume an international role, less attention has been paid to the question of where. One view is that the renminbi will eventually challenge the dollar as the leading global currency. Supporting theories posit that network effects are strong, meaning that if it pays for banks, firms and governments in some countries to do business in renminbi then it will pay for banks, firms and governments in other countries to do so as well, regardless of where they are located. Supporting evidence includes the fact that China engages in merchandise and commodity trade with economies in every part of the world, as befits its position as the largest national exporter. China similarly makes direct foreign investments in every region. From these observations flows the conclusion that the renminbi will ultimately come to rival the U.S. dollar as a global currency.

The alternative is that is that the renminbi is destined to be a leading regional currency, in Asia in particular. Its future international role, in this case, will more closely resemble that of the euro than the dollar. The euro is used as an international unit of account, means of payment and store of value primarily in Europe's neighborhood - in European countries that are not members of the euro area, in other words, and in countries to Europe's immediate east and south. ${ }^{1}$ Empirical studies confirm that the influence of geographical distance on international trade remains significant, reflecting transportation costs, broadly defined. ${ }^{2}$ More strikingly, geographical distance also matters for financial transactions, reflecting the cost and difficulty of acquiring and disseminating information across space. Given how use of a currency in crossborder transactions flows from the geography of those transactions, this implies a bias toward use of a given currency unit in the economic neighborhood of its national issuer. Similar to the role of the euro in Greater Europe, it follows that Asia is the natural region in which the renminbi will come to act as an international currency.

Consistent with this observation, the first seven countries to establish mechanisms for direct trading of their currencies against the renminbi - rather than buying and selling dollars as an intermediate step toward acquiring and disposing of the Chinese currency - were Asian countries. Efforts to foster renminbi internationalization have also relied heavily on developing transactions with an offshore financial center, Hong Kong, whose prominence reflects precisely its location in Asia. These reflections suggest that the renminbi will come to play an important role mainly in the region. ${ }^{3}$

Political scientists for their part argue that the decision to use a currency in cross-border transactions reflects not just economic links with the issuer but also the latter's ability to project political leverage and power. ${ }^{4}$ The dollar has an important role, these analysts observe, in regions where the U.S. has political influence. China is best able to project leverage and power in the

\footnotetext{
${ }^{1}$ For a discussion of the euro's regional dimension see Posen (2009).

2 "The death of distance has been exaggerated," as Anderson and van Wincoop (2004) put it in their survey of the literature on trade costs.

${ }^{3}$ Indeed, some Chinese economists have long argued for renminbi "regionalization," whereby the renminbi should play a central role in Asia. For example, Han and Yuan (2006) argue that China's trade with Asia will incentivize its trade partners in this region to use the renminbi. Greater network effects and benefits from renminbi use in Asia (reduced transaction costs, lower exchange rate risk, etc.) would provide the foundations for RMB regionalization in their view.

${ }^{4}$ See Helleiner and Kirshner (2014) for an overview.
} 
South China Sea and elsewhere in in the Asia-Pacific region, lacking as it does the aircraft carriers and allies needed to project them over longer distances, at least to an equivalent extent. Again the conclusion follows that the renminbi's future is as a regional currency for Asia more than as a global currency in the manner of the dollar.

The rebuttal is that the tyranny of distance is declining with improvements in transportation and information technologies. It may be true that the first seven countries to establish direct trading in renminbi were in Asia, but a growing number of countries in other parts of the world have followed suit. Hong Kong's special status as an offshore renminbi center is now being challenged by newly established centers from Singapore and Frankfurt to London and Toronto. This trend is likely to continue as China relaxes restrictions on use of the renminbi and opens its capital account.

Our goal in this paper is to evaluate these two views of the renminbi's prospective role as an international unit of account, means of payment and store of value for private and official transactions. We begin in Section 2 with a review of the theory and history of international currencies. ${ }^{5}$ In Sections 3 and 4 we then develop the cases for a global and regional role for the renminbi, respectively. Our conclusions, in Section 5, are mixed, reflecting the fact that this paper has not only two views but also two authors.

\section{Theory and History}

Eichengreen (2014) distinguishes two classes of models of international currency status. One class (examples of which include Krugman 1980, 1984; Matsuyama, Kiyotaki and Matsui 1993 and Rey 2001) emphasizes the power of network effects in the international monetary domain. Because of the importance of network increasing returns, once a currency is adopted for international transactions it comes to be used widely. In these models, it pays to do international business in the same currency that one's counterparties use in their own international transactions, including in transactions with third parties.

These network increasing returns can neutralize other disadvantages of using a potential international currency, for example, that the central bank issuing it and therefore acting as liquidity provider of last resort in that unit is in a different region and time zone. From this it follows that once a currency is used in international transactions in some countries, it will come to be used globally. Other implications of this class of models include the fact that first-mover advantage is powerful, that persistence is strong, and that when network increasing returns are especially pronounced, international currency status may be a natural monopoly. Many of these theoretical analyses are motivated by the desire to understand the international role of the U.S. dollar, which is used as an international unit of account, means of payment and store of value globally and not merely, say, in the Western Hemisphere.

The alternative ("new") view of international currency status does not deny the existence of network increasing returns but builds on theoretical work on open systems. ${ }^{6}$ In this view,

\footnotetext{
${ }^{5}$ This has long been a literature that has relied more than most on historical evidence. We observe only a few firstclass international currencies at given points in time (for reasons detailed in the text) and, indeed, over time, limiting the applicability of standard econometric techniques and directing attention instead to historical evidence. We continue in that tradition.

${ }^{6}$ See Farrell and Klemperer (2007) for an overview of the literature.
} 
increasing returns may exist but are not large, and interchangeability costs in high-tech $21^{\text {st }}$ century financial markets are no longer so high. By implication, it is possible to have low transaction costs and stable and predictable prices in cross-border transactions in several national currencies. It follows that other modest advantages (that the liquidity provider of last resort of a currency is in the same time zone or that there are other benefits of proximity, for example) may be determining factors in the decision by a bank, firm or government regarding which currencies to use for international transactions. In this class of models, multiple currencies can play a role in the international domain, with different units being used by different counterparties, including in different locations, as a function of local or regional characteristics.

Proponents of both views draw support from the historical record. Those who subscribe to the old view, point to the dominance of specific currencies in international transactions at different points in time: the pound sterling before 1914 and the U.S. dollar after $1945 .^{7}$ Their analyses highlight how these currencies were widely used in cross-border transactions around the world. They emphasize evidence of persistence or lock-in, with the currencies in question continuing to play global roles even after the share of the issuing country in international transactions had peaked, consistent with a setting in which network increasing returns are strong.

Advocates of the alternative ("new") view argue that a closer look at history reveals that there has always been more than one consequential international currency at a given point in time, and that the use of different currencies has typically had a regional dimension. Lindert's (1969) study showed that the foreign exchange reserves of central banks and governments in 1900 and 1913 were divided between the British sterling, the French franc and the German mark. ${ }^{8}$ Building on Lindert's work, Eichengreen and Flandreau (1996) describe how the mark was held and used mainly in Eastern and Southeastern Europe as well as in parts of Scandinavia, while the franc was used in Western European countries like Spain, Belgium and Switzerland, and the sterling dominated in Latin America and in the British Commonwealth and Empire. ${ }^{9}$

Eichengreen and Flandreau (2009) provide a parallel analysis of the 1920s and 1930s. They find that sterling and the U.S. dollar both featured prominently in the reserve portfolios of central banks and governments, with the sterling playing an important role in Scandinavia (having by this time displaced the German mark), in Portugal and other European members of the so-called sterling area and, as before, in the British Commonwealth and Empire, while the dollar took on a growing role in other parts of the world, including Latin America. ${ }^{10}$ That there were shifts relative to the pre-World War I position, with Scandinavia moving into sterling's camp and the dollar being utilized more widely in Latin America, poses a challenge to the traditional view emphasizing lock-in and persistence. Extrapolated to the future, this suggests

\footnotetext{
${ }^{7}$ There is some dispute about exactly when the dollar overtook sterling as the leading international currency and thus about the identity of the dominant international unit between 1914 and 1945 (see the references below).

${ }^{8}$ Case studies of individual central banks, such as Ugolini (2012) of Belgium, show that this practice also extends backward in time.

${ }^{9}$ Prior to the widespread international adoption of gold convertibility in the 1880 s, they also show, the global system was similarly organized around three units: the gold-based pound sterling, the bimetallic French ecu or napoleon, and the silver-based Maria Teresa thaler.

${ }^{10}$ In addition, a distinct international role was played by the gold-based currencies of the so-called gold bloc (led by the French franc) in the 1930s, when capital and exchange controls became widespread and reliance on foreign exchange (as opposed to gold) reserves declined precipitously.
} 
that there may be greater scope for relatively rapid adoption of the renminbi for cross-border transactions in Asia than globally.

Chitu, Eichengreen and Mehl (2013) show that what was true of governments and their reserves was true of private markets and their assets. Specifically, the currency denomination of international bonds was split more or less evenly between the dollar and sterling in the 1920s and 1930s. Chitu, Eichengreen and Mehl (2014) analyze the roles of economic geography (trade and distance) and history (persistence), establishing a role for both. Eichengreen and Flandreau (2011) provide a parallel analysis of the use of currencies in financing international trade and similarly document the use of different national currencies in various parts of the world.

Another literature examines the use of international currencies during and after the Bretton Woods period. Some authors such as Bergsten (1975) suggest that the Bretton Woods system is properly viewed as a tripartite structure consisting of three blocs based on sterling, the dollar and gold. The interwar and wartime sterling area persisted, while the rest of the world coalesced into gold and dollar blocs. Members of the dollar area (Brazil, Canada, Israel, Japan, Mexico, Norway, Saudi Arabia, Sweden, Thailand, Turkey, Venezuela, Germany from 1967 and Spain from 1970) took the bulk of their exchange earnings in dollars. Members of the gold bloc, in contrast, took fully 75 per cent of their increased reserves in the form of gold in the 1960s. The core members of this post-World War II gold bloc - Belgium, France, Italy, the Netherlands and Switzerland - were not only geographically contiguous but had also been core members of the gold bloc of the 1930 s and, indeed, key members of the $19^{\text {th }}$ century Latin Monetary Union.

Others like McKinnon (1979) argue that the dollar was the dominant international vehicle and reserve currency in transactions among banks and the primary currency of invoice in international commodity trade throughout this period. They refer not to the Bretton Woods and post-Bretton Woods systems but to the "gold-dollar system" through the early 1970s and the "dollar" or "limping-dollar standard" thereafter. Members of this school emphasize the extent to which the international monetary and financial system is still heavily dollar based even today: ${ }^{11}$ Goldberg and Tille (2005) show that the dollar's use in invoicing international merchandise transactions remains far in excess of the U.S. share of global merchandise trade. The dollar is used in 85 per cent of global foreign exchange transactions, far in excess of the U.S. share of global cross-border financial transactions. ${ }^{12}$ And the dollar continues to comprise more than 60 per cent of global identified foreign exchange reserves despite the fact that the U.S.' share of global GDP is no more than 25 per cent. ${ }^{13}$

These observations are consistent with the existence of strong network increasing returns, in the manner of traditional models in which a single national currency dominates international transactions. In the extreme, the implication of this view emphasizing dollar dominance is that in order for the renminbi to become a true international currency it will not only have to supplant the dollar, but that it also will have to do so globally. The rebuttal is that the Bretton Woods and post-Bretton Woods periods were special by virtue of the absence of viable alternatives to the dollar, which was the dominant international currency by default, as no other national unit

\footnotetext{
${ }^{11}$ A recent exemplar of this view is Prasad (2014).

12 This according to the most recent BIS triannual survey of foreign exchange transactions. Note that currency shares in foreign exchange transactions sum to 200 per cent, since two currencies are involved in every such transaction.

${ }^{13}$ Less if purchasing-power-parity based weights are used. Data on reserves are from the IMF's COFER database.
} 
possessed the scale, stability and liquidity needed to render it attractive for widespread crossborder use. This is something that will now change, it is hypothesized, as the renminbi acquires the stability and liquidity required to assume a consequential international role.

If this hypothesis is correct, then the dollar and the renminbi may eventually coexist in the international domain. The question is whether they will both be used globally, in cross-border transactions with counterparties around the world, or mainly in different regions: the renminbi in Asia and the dollar in other parts of the world. ${ }^{14}$

\section{The Case for a Global Currency}

There is no one-to-one mapping between trade and financial transactions with a country on the one hand and the likelihood of using its currency as an international unit of account, means of payment and store of value on the other. But studies establishing this fact also establish a positive association between the two tendencies: that more extensive economic relations with a country increase the likelihood of using its currency in cross-border transactions. This is not surprising given that firms, banks and others in a country will have a natural preference for using their domestic currency in cross-border transactions, in turn conferring on their foreign counterparties an incentive to accommodate that preference. Goldberg and Tille (2005) document this for the choice of currency for invoicing merchandise transactions. The earlier literature has similarly shown that trade and financial transactions with a country, the use of its national unit to settle those transactions, and the need to hold these currencies in foreign reserves go together.

In considering the renminbi's international role, it is therefore relevant to observe that China's foreign trade and financial transactions are widely distributed across regions. Figures 1 and 2 show the geographical distribution of China's imports and exports. Only one quarter of China's exports go to other Asian countries, excluding Hong Kong, Macao and Taiwan, while an additional 24 per cent go to Europe, and 23 per cent to North America. The regional composition of China's imports is more concentrated, but only slightly, with one third of the total drawn from other Asian countries. This difference on the import side reflects China's role in global supply chains, where large volumes of intermediate goods from Asia (industrial materials, parts and components, and semi-finished goods, for example) are imported to be processed for subsequent export (more on which below).

At first glance, the direction of China's foreign direct investment, depicted in Figure 3, is more concentrated, with the majority destined for Hong Kong, Macao and Taiwan. But these offshore centers are serving mainly as intermediaries for Chinese foreign investment ultimately destined for other countries. Excluding offshore centers, Chinese foreign investment is widely distributed, with roughly equal slices directed at Asia, Europe and Latin America. This reflects investments by Chinese enterprises in commodity- and energy-related sectors as well as manufacturing.

\footnotetext{
${ }^{14}$ One can also imagine a hybrid outcome, where the renminbi is used mainly in Asia while the dollar is used globally, including in Asia. We consider this possibility below.
} 
Figure 1. Regional Composition of China’s Exports, 2013

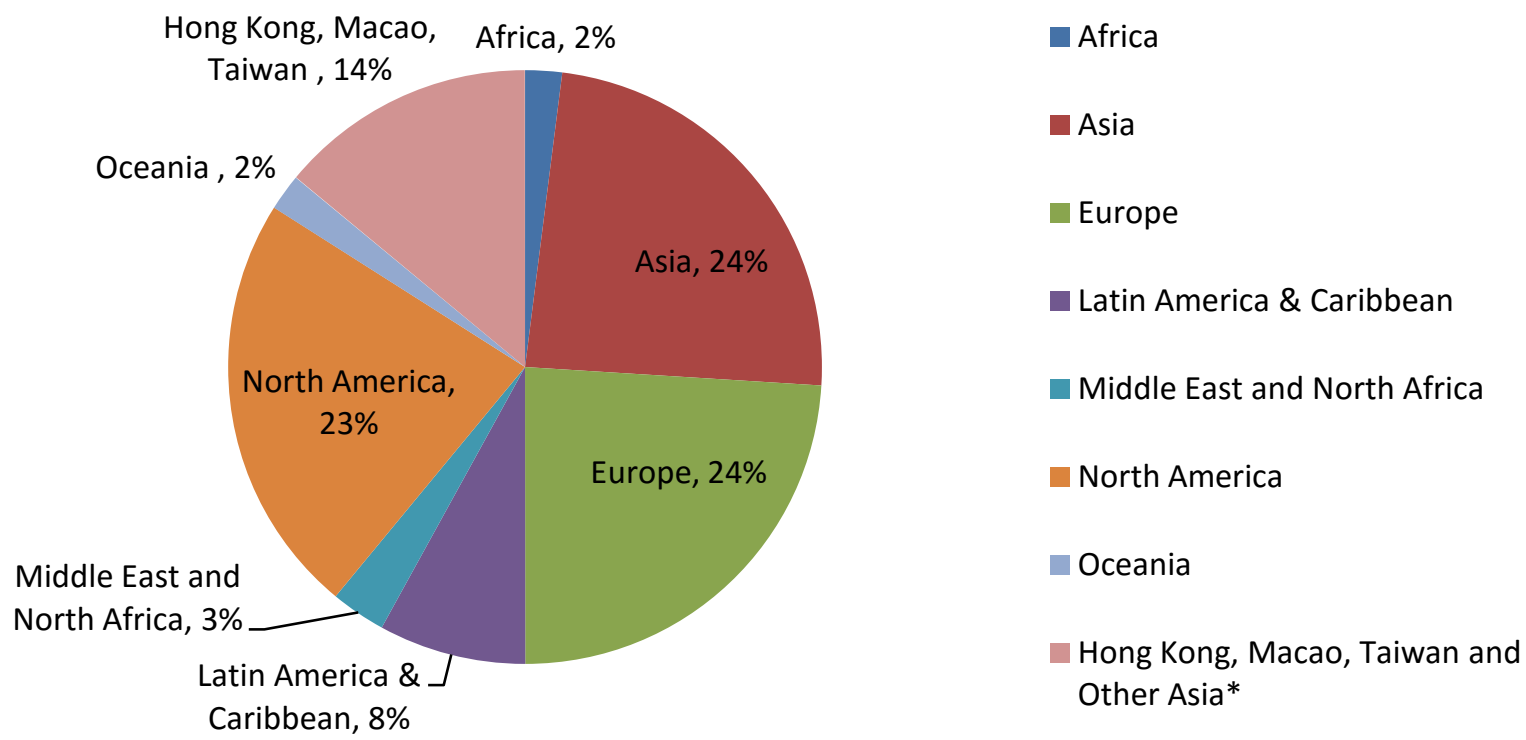

Source: UN Comtrade Database.

*Taiwan is included in Comtrade data under "Other Asia, not elsewhere specified". A small portion may include Other Asia, not elsewhere specified. See http://unstats.un.org/unsd/tradekb/Knowledgebase/Taiwan-Province-ofChina-Trade-data.

Figure 2. Regional Composition of China’s Imports, 2013

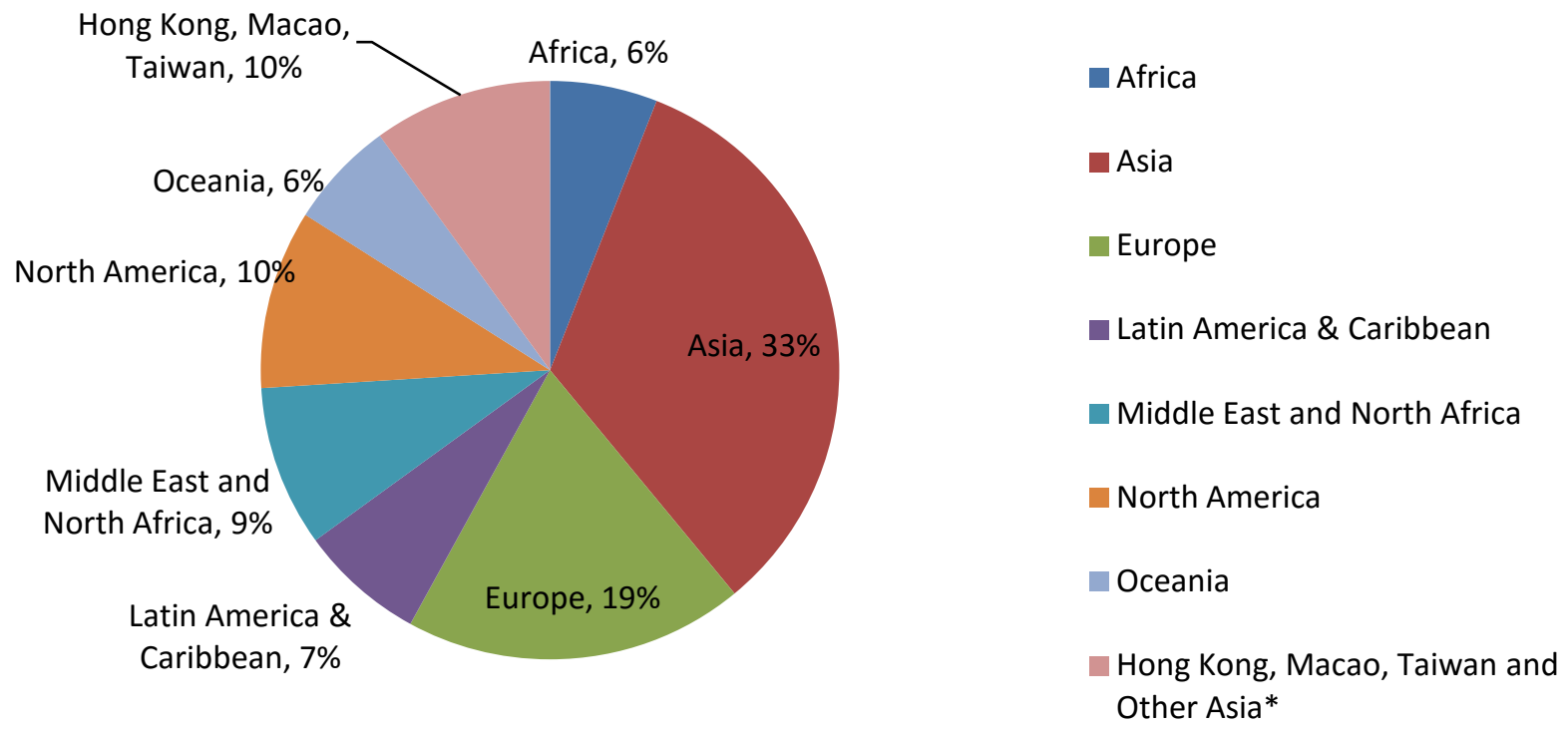

Source: UN Comtrade Database.

*Taiwan is included in Comtrade data under "Other Asia, not elsewhere specified". A small portion may include Other Asia, not elsewhere specified. See http://unstats.un.org/unsd/tradekb/Knowledgebase/Taiwan-Province-ofChina-Trade-data.

Likewise, China's free trade agreements (FTAs) reflect its geographically diversified trade and investment flows. Although the country's early FTAs were with countries in Asia 
(ASEAN in 2004, Pakistan in 2006, Singapore in 2008), China has since negotiated agreements with countries in other parts of the world (including, to date, Chile, Peru, Costa Rica, Iceland and Switzerland; see Table 1). FTAs under discussion or likely to be under discussion in the future suggest that this geographically diversified approach to negotiations will persist.

With the growth of China's trade and financial links comes an incentive to conduct transactions in renminbi. In turn, this creates an incentive to stabilize a trade partner's local currency against the renminbi, which encourages the central banks of these countries to hold renminbi-denominated foreign exchange reserves and establish contingent renminbi liquidity lines with the People's Bank of China (PBOC).

Is this last tendency limited mainly to Asia or observed more widely? To address this issue, Subramanian and Kessler (2013) estimated "Frankel and Wei regressions," where the value of the local currency against a numeraire, in this case the Swiss franc, is taken as a function of the renminbi/franc, dollar/franc, yen/franc and euro/franc rates. ${ }^{15}$ We update their results for a sample of 41 countries, as shown in Appendix A, for the period July 2012-July 2015. Following Subramanian and Kessler, we identify the dominant reference currency as the currency with the largest effect on the exchange rate of the countries considered.

As one would expect, we find the dollar to be the dominant reference currency for many countries throughout the Americas, Asia, Europe and the Middle East. The euro tends to be the dominant reference currency mainly for European countries. Interestingly, the renminbi is the dominant reference currency in Asia, and in particular for the ASEAN economies.

Figure 3. Regional Composition of China’s Overseas Direct Investment, 2013

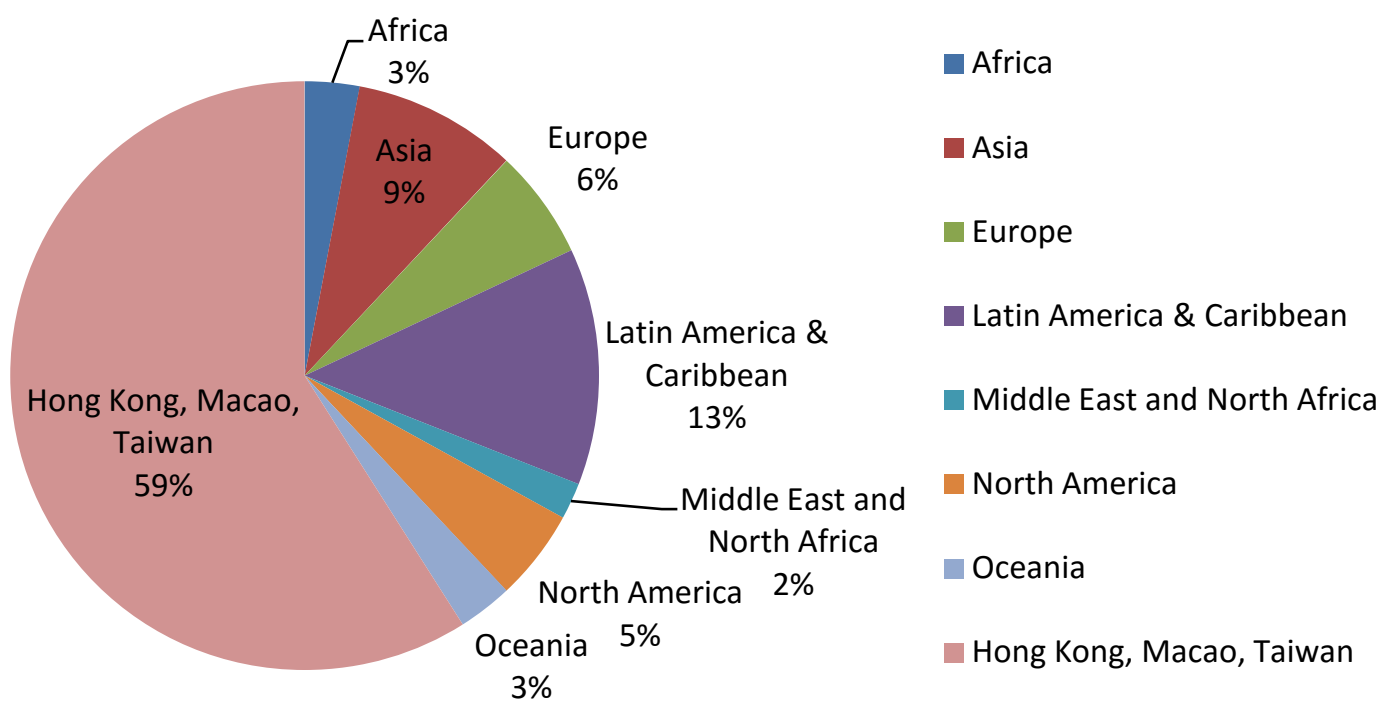

Source: CEIC Database.

In addition to having the strongest effect in a number of Asian countries, the renminbi also has a significant effect in several European countries, according to these results, and a

\footnotetext{
${ }^{15}$ Frankel and Wei (2008) provide an overview of the methodological approach.
} 
statistically significant effect in a number of South American and European countries as well. ${ }^{16}$ The renminbi tends to be important for Russia and Ukraine in Europe, as well as for countries elsewhere such as India, Israel, Macedonia and Peru. We show in Appendix A, again following Subramanian and Kessler, that the weight on the renminbi is plausibly a function of commercial and financial links between a given country and China. And, as documented above, those commercial and financial links are as much global as regional.

The question of whether the renminbi's future is mainly as a regional or global currency should be addressed from an institutional perspective as well. Beijing has used the China Development Bank and Export-Import Bank of China, for example, to promote renminbidenominated lending and settlement. Countries to which these institutions lend and receive funds in renminbi, which they then use to finance imports of merchandise from China and to purchase the services of Chinese construction companies. While a significant share of the lending by these state banks is to other Asian countries, a non-negligible share is to countries and companies outside the region (to the government of Venezuela in 2010, for example, and to small and medium-size enterprises in a variety of African countries).

China has recently sponsored the creation of the Asian Infrastructure Investment Bank (AIIB) to promote infrastructure investment in the Asia-Pacific region and, not incidentally, to create business for Chinese construction companies. It can be argued that with China providing much of the funding and Chinese construction companies doing the work, the AIIB will foster use of the renminbi mainly at the regional level (we explore this possibility further in Section 4 below). Although the AIIB's current objective is to contribute to Asian infrastructure development and regional integration, membership is global, not regional, with 57 prospective founding members at the time of writing. These include 24 countries in Asia, 20 in Europe and 9 in the Middle East (see Appendix C, Table 2). These countries will all be contributing capital to the bank, and their construction companies and consultants will similarly be competing for business. It therefore will not be surprising to see the AIIB expand its operations to developing countries outside of Asia.

Other institutional bases for wider international use of the renminbi include swap lines with the PBOC, the designation of a Chinese financial institution as official clearing bank for settling renminbi-denominated transactions, and a quota for investing in China's local-currency equity market (an RQFII quota). Weir (2015) refers to these initiatives as the "three gifts," since they require negotiation and agreement with the Chinese authorities and since they tend to go together. They represent implicit endorsement by the Chinese authorities of a center's offshore RMB status.

In practice, these arrangements extend far beyond Asia. Table 3 lists offshore clearing banks in foreign financial centers by date of establishment. These centers now include many cities outside of Asia and across the globe, including inter alia Frankfurt, London, Paris, Sydney and Toronto. Indeed, virtually every important financial hub is now a designated renminbi offshore center with the exception of New York. If we exclude Hong Kong, Macau and Taipei, which played strategic roles in the early development of the offshore renminbi market, only four

\footnotetext{
${ }^{16}$ This is in contrast to the euro, whose effect is limited to other European countries, and the dollar, which according to this methodology, is the most important exchange rate for countries in a variety of different regions, as befits a global currency.
} 
Asian cities are designated offshore renminbi centers, compared to four in Europe and three in the rest of the world. In terms of geographic distribution, there is no obvious bias favoring Asia.

Having an official clearing bank matters because access to the renminbi is limited, since access to Chinese financial markets is limited. This designation creates a presumption that the bank in question will clear transactions in renminbi for offshore counterparties. One can argue that the presence of an official clearing bank will matter only for a transitional period, since all foreign banks will have access to the onshore renminbi market once China's capital account is fully open and official clearing banks will then have no advantage. If, on the other hand, there is a path-dependent aspect to financial development, then official clearing bank status can have persistent effects on the geography of international finance. ${ }^{17}$ Hong Kong was the first offshore RMB center, and for ten years until October 2013 had the only official offshore RMB clearing bank. Since then, six additional clearing banks have been designated for Asian countries, and seven have been designated for non-Asian countries (for these purposes we classify Qatar as a non-Asian country).

The renminbi-qualified institutional investor (RQFII) program allows designated institutional investors to invest in renminbi-denominated assets in China. Virtually all countries with official clearing banks have RQFII quotas (see Table 4). Possession of an RQFII quota encourages local fund managers to source renminbi credit for use in investing in Chinese markets. However, some fund management companies have been able to access RQFII quotas in more than one jurisdiction, and aside from the case of Hong Kong, few if any of these quotas have been fully taken up. Both observations raise questions about whether these quotas will significantly affect the location of renminbi-denominated business. ${ }^{18}$ To the extent that they do, further allocation of such quotas weakens their original Asia- and specifically Hong Kongcentric bias.

Central banks in a large set of countries in Asia and other regions - 30 at the time of writing - now have swap lines with the PBOC (see Table 5). Thirteen of these bilateral swap arrangements are with Asian central banks, while eleven are with European central banks and others are with central banks in additional parts of the world. China's third largest swap line (after that with Hong Kong SAR and South Korea) is with the European Central Bank, reflecting the fact that China is the European Union's second largest export market. These lines are useful for providing renminbi liquidity where official clearing banks have not been designated and for supplementing official clearing bank liquidity where they have. Access to renminbi funds can be essential in a crisis. In the absence of such access, the local authorities will be reluctant to permit resident banks and firms to acquire renminbi exposure. In a handful of locations, notably Hong Kong, the PBOC swap line is also regularly resorted to by the local monetary authority as a mechanism for enhancing the liquidity of local renminbi markets and encouraging commercial and financial business in the currency.

Garcia-Herrero and Xia (2013) and Liao and McDowell (2014) have analyzed who is on the receiving end of these arrangements and why. We follow them in analyzing the determinants of their incidence, using an updated list of swap agreements for 166 countries. The dependent

\footnotetext{
${ }^{17}$ Models of international financial centers based on increasing returns (in this case not exclusively of the network variety) often generate this kind of path-dependent result. See Gehrig (2000) for further discussion.

${ }^{18}$ See, again, Weir (2015).
} 
variable is possession of a bilateral swap arrangement with the PBOC, while explanatory variables include economic size, trade and financial integration with China, distance from China, and a variety of other macroeconomic indicators. To capture regionalization, we add a dummy variable for Asian countries. This allows us to test whether Asian countries are ceteris paribus more likely than countries in other parts of the world to receive swap lines from the PBOC.

As shown in Appendix B, the dummy variable for Asian countries is uniformly indistinguishable from zero whether the relationship is estimated by probit (with a zero/one dummy as the dependent variable), ordered probit (distinguishing small and large swap arrangements) or tobit (where the amount of the swap line, which may be zero, is included as the dependent variable). The PBOC does not appear to prefer Asian countries when extending bilateral swap arrangements, or so it would appear after controlling for other variables such as the size of the economy, financial and trade flows and inflation. ${ }^{19}$

Finally, China has supplemented these bilateral renminbi swaps with the BRICS Bank and Contingent Reserve Arrangement (CRA). Through the BRICS Bank, members will lend money to one another for development projects, where some of that money will presumably be denominated in the currency of the lender. Under the CRA, participating central banks will be able to draw up to $\$ 100$ billion of international reserves from one another, subject to conditions. China has made the largest initial commitment, of $\$ 41$ billion, to the CRA.

Revealingly, China's partners in this arrangement include countries outside Asia (Brazil, South Africa) as well as countries within it (India and Russia). CRA capital allocations and quotas are shown in Table 6. But it is not clear whether CRA lending by China will be in dollars or renminbi. (The initial BRICS CRA treaty refers to dollars.) The CRA cannot therefore automatically be viewed as a mechanism for promoting use of the renminbi within the region.

\section{The Case for a Regional Currency}

While the renminbi is an increasingly popular global payments currency, it still lags significantly behind the dollar. Its 2.79 per cent share of global payments is dwarfed by the 45 per cent share of the dollar. ${ }^{20}$ The dollar is still the preferred reserve currency (Kawai and Pontines 2014). The dollar is still far and away the dominant currency in global foreign exchange markets, where it is involved fully in 85 per cent of all transactions, according to the Bank for International Settlements' most recent triennial survey. ${ }^{21}$ These facts reflect the dollar's firstmover advantage, the depth and liquidity of U.S. financial markets, the close commercial and financial ties of other countries with the U.S. economy that remain larger than China's at market exchange rates (market exchange rates being what matter for international transactions) and America's geopolitical and military leverage (which, if in decline, remains considerable).

\footnotetext{
${ }^{19}$ That said, certain patterns beyond geography do emerge. Countries with relatively open capital accounts, for instance, are significantly less likely to obtain swap lines with the PBOC. Unsurprisingly, countries that are large in terms of GDP, trade extensively with China, or have institutional ties with China through a FTA are more likely to obtain a swap arrangement.

${ }^{20}$ According to Swift data released on October 6, 2015, https://www.swift.com/about_swift/shownews?param_dcr=news.data/en/swift_com/2015/PR_RMB_special_edition sibos.xml.

${ }^{21}$ Note that currency shares in foreign exchange transactions sum to 200 per cent, since two currencies are involved in every transaction. On the triennial survey see http://www.bis.org/publ/rpfx13.htm .
} 
The alternative is to argue that the renminbi is destined to become an important vehicle for cross-border transactions, not so much globally, but in Asia. This argument is lent plausibility by China's strong trade ties with its Asian neighbours. It is supported by the fact that China has been running persistent trade deficits with the rest of Asia, thereby enabling other Asian countries to accumulate the renminbi-denominated reserves needed to operate a renminbi-based system (Chey 2012). ${ }^{22}$ Swift data on international payments are consistent with these presumptions. While they show that the renminbi is the vehicle for less than 3 per cent of payments worldwide, it is already used in the majority of payments with China and Hong Kong themselves.

Thus, if the renminbi is to play an international role, the argument follows, it is most likely to do so in Asia where it has special advantages. This can be argued on three grounds. First, there are economic reasons for thinking that China and other Asian countries are natural trade and financial partners. ${ }^{23}$ Using data for China's GDP and imports from other East Asian economies, $\mathrm{Li}, \mathrm{Li}$ and Ding (2004) document the existence of an exceptionally large elasticity of China's imports from other East Asian economies with respect to Chinese GDP. Given the prospect of rapid Chinese GDP growth, they conclude that China will become the largest trading economy in East Asia in the next twenty years, with about half of its imports coming from the region. According to data from the General Administration of Customs of China, China's imports from major East Asian economies (Hong Kong, Japan, South Korea, India and ASEAN) already account for 38 per cent of its total imports, while imports from Asia as a whole (including the West and Central Asian countries) represent 55 per cent of its total imports (estimates for 2014). ${ }^{24}$

Underlying these patterns is the fact that trade costs, broadly defined, still matter importantly for cross-border commercial transactions, and distance is still relevant to trade costs. ${ }^{25}$ Transport costs are a significant portion of total trade costs (where the latter include also costs of insurance, time in transit, local distribution and so forth). Abe and Wilson (2009), for their part, confirm that transport costs increase with distance. More generally, these costs can be inferred from differences in the prices of the same products in different countries Feenstra [1998] famously contrasts the cost in different markets of Mattel's Barbie Doll), from the difference between the inclusive cost of insurance and freight (cif) and free on board (fob) prices, and from the predominant mode of transportation (and from the posted costs of utilizing that mode). To be sure, the association of transport costs with distance varies with the presence or absence of natural ports, long coastlines and mountain ranges. But none of this changes the fact that Asian countries, and in particular, those that border the South China Sea, are natural trade partners. ${ }^{26}$

\footnotetext{
${ }^{22}$ China's trade structure is characterized by a trade surplus with developed countries in North America and Europe and a trade deficit with economies in East Asia.; this can, in turn, facilitate renminbi's exports in the emerging East Asian economies (Huo and Yang 2013).

${ }^{23}$ And for thinking, as argued above, that use of a currency in cross-border transactions is associated with importance of the issuing country in the associated commercial and financial transactions.

${ }^{24}$ The percentages here are calculated by the data from the General Administration of Customs of the People's Republic of China. The data is available at: http://www.customs.gov.cn/publish/portal0/tab49667/info730459.htm.

${ }^{25}$ A survey of the literature on trade costs is Anderson and van Wincoop (2004).

${ }^{26}$ Limao and Venables (1999) estimate the determinants of the cost of shipping for a standard 40-foot container from Baltimore to various destinations. The elasticity with respect to distance is 0.38 . An extra 1,000 kilometers of
} 
Another way of gauging whether economies are natural trade partners, deriving from Ricardian and Heckscher-Ohlin trade theories, is on the basis of relative resource endowments. There is no question that resource endowments vary widely within Asia. For example, China is poorly endowed in certain natural resources compared to some of its Asian neighbours: it possesses little in the way of clean fossil fuels compared to, say, Malaysia, and is the world's largest petroleum importer. ${ }^{27}$ Further, its labour force peaked in 2010, and as a result, unskilled labour is becoming increasingly scarce relative to say, Indonesia, India and Bangladesh. It follows that China will export goods embodying skilled and semi-skilled labour and capital and import goods that make more intensive use of raw materials, energy and unskilled labour - again making Asian countries like Indonesia, India and Bangladesh natural trading partners. Consistent with this presumption, trade amongst the economies in question has been growing more rapidly than global trade, and more rapidly than China's trade overall. ${ }^{28}$

Another dimension to consider is intra-industry trade. Due to the development of international supply chains, different countries specialize in different (vertical) stages of a production process and produce different components of a final product or set of products. This has been a large component of Asian trade flows throughout the rapid economic development of Asia since the mid-1980s. China has long been involved in these regional supply chains, most prominently in the case of consumer electronics, importing semiconductors from Japan, South Korea and Taiwan, and combining them with other components before exporting a final product. ${ }^{29}$ On the demand side, it is likely that Asia will become an increasingly important destination for these Chinese products, as these countries increase income and wealth per capita and develop their middle classes. Accordingly, intra-industry trade between China and other Asian countries is likely to increase further, which will provide consistent momentum for intraindustry trade and for renminbi use for cross-border transactions in the region (Han and Yuan 2006).

It can be objected that many of the supply chains in which China is involved are global, not regional: for example, the country imports iPhone design from Sunnyvale, California before exporting the assembled product back to the United States. But with the articulation of supply chains, production has grown increasingly susceptible to disruption by climatic and political shocks. ${ }^{30}$ As these risks come to be better appreciated, producers have relocated supply chainrelated production to sites closer to the point of final sale, which are less susceptible to natural

straight line distance adds $\$ 380$ to the cost, in other words. When land and sea distance are distinguished, both are significant, and the effect of the latter is seven times the effect of the former in magnitude.

${ }^{27}$ World Bank data put China's net energy imports at 11 per cent of GDP, not a large fraction by international standards, but a large absolute amount. For energy, the country has relied on coal-fired power plants, which may not be environmentally feasible in the future. While there is natural gas in the country's western provinces, China lacks the water needed to frack it. There is also the possibility of large oil and gas reserves offshore, but that is speculative and part of a different discussion.

${ }^{28}$ Thus, ASEAN's three fastest growing individual markets in recent years have been China, South Korea and Australia (Standard Chartered 2014).

${ }^{29}$ China is now moving up-market, specializing in the production of more sophisticated components and outsourcing lower-value-added components such as assembly to lower-wage economies like Vietnam, but this doesn't change the point.

${ }^{30}$ Examples include the 2011 floods in Thailand, which disrupted the production of Chinese consumer electronics, Japanese motor vehicles and Apple iPhones, among others, by interrupting the supply of key components, and port strikes that disrupted the importation of not just components but also final products. Other risks include other types of natural disaster, strikes, civil unrest and political turmoil. 
and economic disruptions and where political conditions, by virtue of their proximity, are better understood. A case in point is how U.S. firms in a variety of industries have relocated the production of components from China and other Asian countries to Mexico. ${ }^{31}$ These observations point to the likelihood that we will continue to observe the disproportionate growth of intra-Asian trade.

There is an abundance of evidence suggesting that distance also continues to play a role in international financial transactions. Portes and Rey (2000) and Portes, Rey and Oh (2001) study cross-border financial transactions in U.S. equities and bonds and show that distance still matters after controlling for other determinants of the volume of these transactions. Analyzing foreign direct investment flows, Brainard (1997), Gao (2009) and Paniagua (2011) show that such flows vary inversely and significantly with distance. Di Giovanni (2002) similarly shows that distance matters for cross-border mergers-and-acquisitions-related capital flows. The association between cross-border financial flows and proximity presumably reflects costs of information acquisition and corporate control which historically have tended to increase with distance. To the extent that this remains the case today, the observation points to the disproportionate growth of cross-border financial transactions within Asia and a role for the dominant regional currency in those transactions.

A second basis for arguing that the renminbi is likely to be an important vehicle for crossborder transactions mainly in Asia, points to Asia-specific institutional and policy initiatives undertaken with impetus from Beijing. To start, China's Silk Road Initiative was designed to promote trade and economic integration in Central Asia. Also known as the "Belt and Road Initiative," this was laid out by President Xi Jinping in visits to Central and Southeast Asia in 2013 and has been backed by the country's National Development and Reform Commission. The plan envisages enhanced connectivity within and among Asia, Europe and Africa via land and adjacent sea routes, although it appears to be centered on Central and Southeast Asia. The Silk Road Economic Belt will run along the historic Silk Road trade route, which stretches from coastal China through Central Asia, while the Maritime Silk Road will connect China's south with Southeast Asia. ${ }^{32}$ Although focused on transport and other forms of physical infrastructure, the Silk Road Initiative is also intended to encompass trade facilitation, financial cooperation and cultural exchange. Insofar as it achieves its goal of reducing transport costs, cultural barriers and other obstacles, it has the potential to deepen on one hand, trade and financial interaction with China, and on the other hand, Southeast and Central Asian countries, thereby enhancing the attractiveness of use of the renminbi in this region.

China also participates in a number of regional initiatives together with the ASEAN countries. As noted above, it signed a free trade agreement with ASEAN in 2002, which came into operation in 2010. An FTA agreement with South Korea was also recently signed. These agreements will encourage additional trade flows between China and its Asian partners.

That said, the impact of these Asian FTAs should not be exaggerated. Poorer members of ASEAN have repeatedly been given additional time to phase out their tariff barriers, and all

\footnotetext{
${ }^{31}$ Part of this is the familiar issue of transportation costs. According to Offshore Group (2013), shipping goods from China to the U.S. costs $\$ 5,000$ a container, while shipping the same container from Mexico costs $\$ 3,000$. And there is the obvious point that labour costs have been rising in China relative to Mexico.

${ }^{32}$ There are also proposals under the Silk Road rubric to establish transport corridors linking China and Pakistan.
} 
participants have been allowed to submit extensive lists of sensitive sectors whose products are excluded. Still, these FTAs have been responsible for some movement in the direction of freer trade in the region, and they signal more of the same in the future. For instance, Huo and Yang (2013) estimate that, during 1998-2010, the Trade Combined Degree (TCD) index between China and ASEAN is consistently above one, which points to closer economic ties between the two regional economies. They calculate the average Grubel-Lloyd (GL) index for intra-industry trade between China and five major economies within ASEAN (Singapore, Malaysia, Philippines, Thailand and Indonesia) and find that the index was increasing in the period 20012010, reflecting a rising degree of industrial complementarity and deepening economic integration between China and ASEAN. They conclude that a high TCD index, extensive intraindustry trade and growing diversity of products all underscore deepening economic and trade relations between China and the ASEAN countries.

Moving from trade to financial integration, China was a founding member in the Asian Bond Market Initiative (AMBI) established by the ASEAN+3 countries following the 1997-1998 Asian financial crisis. The ABMI is intended to promote the growth and integration of regional debt security markets, and markets in local currency debt securities in particular, by sharing information on best practices and applying pressure for adoption. It was then followed by the creation by the same countries of an Asian Bond Market Forum (ABMF) of regular meetings between private-sector experts and officials with the goal of harmonizing regulation and standardizing market practices across the region, in this case with the explicit goal of promoting cross-border transactions in local-currency-denominated debt securities. Insofar as standardization includes standardization on a specific local currency, the currency in question will plausibly be that of the largest issuer, namely China.

Further, China is the largest contributor, along with Japan, to the Chiang Mai Initiative Multilateralization (CMIM) through which the ASEAN+3 countries have agreed to extend swap lines and credits to one another. This is a regional supplement to the global network of central bank swap lines, including the PBOC swap lines described in Section 3. It was established in 2000 as the Chiang Mai Initiative (CMI), a network of bilateral swaps, and reorganized in 2010, nominally as a single reserve pool, now amounting to $\$ 240$ billion. China (including Hong Kong) and Japan each contribute 32 per cent of the collective reserve pool (for national contributions see Table 7). Most of the swap arrangements are specified as swaps of local currencies for U.S. dollars, but four - China-Japan, China-Philippines, China-Korea and JapanKorea - involve the partners' local currencies. In addition to the practical uses of swap arrangements, the CMIM and the other China-ASEAN initiatives provide a signal that China and ASEAN are willing to cooperate in developing a larger regional network.

Like other swaps, the availability of local-currency lines of credit through the CMIM will encourage regulators to permit banks and firms under their jurisdiction to incur exposures in foreign currencies, since local central banks gain the power to engage in at least limited lastresort lending in those currencies. It is worth noting that the renminbi is the currency that appears most frequently in this connection (in three out of four cases). The CMIM thus provides a natural institutional platform for the renminbi in the ASEAN+3 region.

Additional use of the renminbi by commercial banks and enterprises in the region should in turn encourage Asian central banks to hold more renminbi in their reserve portfolios, enabling them to stabilize the renminbi-local currency exchange rate and act as lender of last resort in 
renminbi to the banks and firms in question. In fact, the majority of ASEAN+3 central banks already have indicated that they have added the renminbi to their reserve portfolios. Early adopters include Malaysia, Cambodia, Philippines, Singapore and Thailand (for the complete list, with dates, see Table 8).

A further basis for arguing that the renminbi's future is as an international currency in Asia builds on the same observations as in Section 3 but applies a different spin. The results in Appendix A show that the vast majority of exchange rates in whose determination the renminbi now has the greatest weight are Asian currencies. The countries with the largest RQFII quotas (Hong Kong, Singapore and Taiwan) are Asian countries. The recently-created Shanghai-Hong Kong Stock Connect, which removes barriers between equity markets in Shanghai and offshore, specifically removes those barriers between Shanghai and a principal Asian market. Moreover, the first seven countries with direct trading of their local currencies against the renminbi - Laos, Kazakhstan, Vietnam, Korea, Thailand, Japan and Australia - were all Asian countries, as were the first countries to add the renminbi to their reserve portfolios - Hong Kong and Malaysia.

Finally, insofar as political power and leverage matter for international currency use, it is worth noting that China is best able to project such power and influence in the South China Sea and elsewhere in Asia. In terms of economic influence, there is no doubt that China plays a large role for Asian countries like Thailand, Malaysia and Vietnam, as China is one of their most important trade and financial partners. Consistent with this, Asian countries' willingness to participate in institutional arrangements with China reflects the fact that the same countries benefit from these relationships with China. All these are reasons for believing that the renminbi's future is as a leading regional, not global, currency.

\section{Conclusion}

Forecasting is difficult, especially when it involves the future. Any forecast about whether the renminbi's future is as a global or regional currency should therefore be taken with a grain of salt. So instead of forecasting, we have done our best in this paper to make the cases for both scenarios. Neither theory nor history points unambiguously in one or the other direction, and modern evidence can be marshaled in support of both views. On the one hand, China has increasingly important economic, financial and political links with countries not only in Asia, but throughout the world, just as China invests globally, and not just in Asia. Many of China's policy initiatives, such as negotiating bilateral free trade arrangements, designating Chinese banks as official renminbi clearing banks for foreign financial centers, and concluding renminbi swap arrangements with foreign central banks, extend also to countries in Europe and the Western Hemisphere. These observations suggest that as Chinese financial markets gain depth and liquidity, the renminbi will assume a role not merely as a currency used in settling trade-related transactions, where it already functions, but also as an investment and reserve currency, not just in Asia but globally.

At the same time, however, some of China's deepest and most natural economic, financial and political links are with neighboring Asian countries. Transport costs are still important factors for international trade, and they are lowest over short distances. Distance also matters for international financial transactions, whether because local knowledge dissipates with distance or because certain financial transactions are more costly across multiple time zones. These facts make China and other Asian countries logical commercial and financial partners. 
Asian countries that see themselves as sharing common characteristics, and specifically common economic and financial vulnerabilities, have responded with regional initiatives like the Asian Bond Market Initiative, Asian Bond Forum, Asian Bond Fund, Chiang Mai Initiative Multilateralization and ASEAN-China Free Trade Agreement, all of which work to further deepen economic and financial integration in the region. This suggests that the renminbi, as the currency of the largest Asian economy and leading trader, has a natural habitat in the region, and that its future is as the leading Asian currency.

As for which scenario is more likely, one can only echo Zhou Enlai (speaking not of the French Revolution but of the French student demonstrations of 1968, in actual fact), that it is too early to tell. This paper at least identifies some of the principal factors on which the answer will hinge. 
Table 1. Existing and Prospective Free Trade Agreements

\begin{tabular}{ll}
\hline Country & Date \\
Bi-lateral FTAs & \\
Developing Countries & \\
Pakistan & November 2006 \\
Chile & November 2005 \\
Peru & April 2009 \\
Costa Rica & April 2010 \\
Developed Countries & \\
New Zealand & \\
Singapore & April 2008 \\
Iceland & October 2008 \\
Switzerland & April 2013 \\
South Korea & July 2013 \\
Australia & June 2015 \\
Multi-lateral FTAs & June 2015 \\
ASEAN & \\
FTA under Negotiation & November 2004 \\
Gulf Cooperation Council & \\
Regional Comprehensive Partnership & July 2004 \\
ASEAN FTA Upgrade & May 2013 \\
Norway & September 2014 \\
Japan and Korea & September 2008 \\
Sri Lanka & January 2013 \\
FTA under Consideration & September 2014 \\
India & \\
Colombia & 2003 \\
Maldives & N/A \\
Georgia & February 2015 \\
Moldova & April 2015 \\
\hline Source: Whalley and Li (2014), Ministry of Commerce, China (2015) \\
\hline
\end{tabular}


Table 2. Prospective Founding Members of Asian Infrastructure Investment Bank

\section{East Asia and Pacific (12) \\ Brunei, Cambodia, China, Indonesia, Laos, Malaysia, Mongolia, Philippines, Republic of Korea, Singapore, Thailand, Vietnam.}

Other Asia (12)

Azerbaijan, Bangladesh, India, Kazakhstan, Kyrgyz Republic, Maldives, Myanmar, Nepal, Pakistan, Sri Lanka, Tajikistan, Uzbekistan.

\section{Oceania (2)}

Australia, New Zealand.

Middle East (9)

Egypt, Iran, Israel, Jordan, Kuwait, Oman, Qatar, Saudi Arabia, United Arab Emirates.

Western Europe (15)

Austria, Denmark, Finland, France, Germany, Iceland, Italy, Luxembourg, Netherlands, Norway, Portugal, Spain, Sweden, Switzerland, United Kingdom.

\section{Other Europe (5)}

Georgia, Malta, Poland, Russia, Turkey

\section{South America (1)}

Brazil

\section{Africa (1)}

South Africa

Source: AIIB.org (2015). 
Table 3. Offshore RMB Centers

\begin{tabular}{llll}
\hline Country & City & Date & Bank \\
China SAR & Hong Kong & 2003.12 & Bank of China \\
\hline China SAR & Macau & 2004.08 & Bank of China \\
Taiwan & Taipei & 2012.12 & Bank of China \\
Singapore & Singapore & 2013.04 & Industrial and Commercial Bank of China \\
\hline United Kingdom & London & 2014.06 & China Construction Bank \\
Germany & Frankfurt & 2014.06 & Bank of China \\
\hline South Korea & Seoul & 2014.07 & Bank of Communications \\
France & Paris & 2014.09 & Bank of China \\
Luxembourg & Luxembourg & 2014.09 & Industrial and Commercial Bank of China \\
Qatar & Doha & 2014.11 & Industrial and Commercial Bank of China \\
\hline Canada & Toronto, Vancouver & 2014.11 & Industrial and Commercial Bank of China \\
Malaysia & Kuala Lumpur & 2014.11 & Bank of China \\
Australia & Sydney & 2014.11 & Bank of China \\
Thailand & Bangkok & 2015.01 & Industrial and Commercial Bank of China \\
\hline
\end{tabular}

Source: Bloomberg, BOC, ICBC, MAS, PBoC, Reuters, UK Gov, WSJ.

Table 4. RMB QFII Quotas

\begin{tabular}{lll}
\hline Country & Quota (RMB billions) & Date Announced \\
Hong Kong, China & 270 & December, 2011 \\
Singapore & 50 & October, 2013 \\
United Kingdom & 80 & October, 2013 \\
France & 80 & March, 2014 \\
South Korea & 80 & July, 2014 \\
Germany & 80 & July, 2014 \\
Qatar & 30 & November, 2014 \\
Canada & 50 & November, 2014 \\
Australia & 50 & November, 2014 \\
\hline
\end{tabular}

Source: Hatzvi, Nixon and Wright (2014). 
Table 5. Swap Arrangements with the People’s Bank of China

\begin{tabular}{lll}
\hline Country & Date & Amount in Yuan \\
\hline Albania & 2013.09 & 2 billion \\
\hline Argentina & 2009.03 & 70 billion \\
\hline Argentina & 2014.07 & 70 billion \\
\hline Armenia & 2015.03 & 1 billion \\
\hline Australia & 2012.03 & 200 billion \\
\hline Australia & 2015.04 & 200 billion \\
Belarus & 2009.03 & 20 billion \\
Brazil & 2013.03 & 190 billion \\
\hline Canada & 2014.11 & 200 billion \\
\hline European Union & 2013.10 & 350 billion \\
\hline Hong Kong & 2009.01 & 200 billion \\
Hong Kong & 2011.11 & 400 billion \\
\hline Hong Kong & 2014.11 & 400 billion \\
\hline Hungary & 2013.09 & 10 billion \\
Iceland & 2010.06 & 3.5 billion \\
\hline Iceland & 2013.09 & 3.5 billion \\
Indonesia & 2009.03 & 100 billion \\
\hline Indonesia & 2013.10 & 100 billion \\
Kazakhstan & 2011.06 & 7 billion \\
\hline Kazakhstan & 2014.12 & 7 billion \\
\hline Malaysia & 2009.02 & 80 billion \\
\hline Malaysia & 2012.02 & 180 billion \\
\hline Mongolia & 2011.05 & 5 billion \\
\hline Mongolia & 2012.03 & 10 billion \\
\hline Mongolia & 2014.08 & 15 billion \\
\hline New Zealand & 2011.04 & 25 billion \\
\hline New Zealand & 2014.05 & 25 billion \\
\hline Pakistan & 2011.12 & 10 billion \\
\hline Qatar & 2014.11 & 35 billion \\
\hline Russia & 2014.10 & 150 billion \\
\hline Singapore & 2010.07 & 150 billion \\
\hline Singapore & 2013.03 & 300 billion \\
\hline South Korea & 2008.12 & 180 billion \\
\hline South Korea & 2011.10 & 360 billion \\
\hline South Korea & 2014.10 & 360 billion \\
\hline Sri Lanka & 2014.09 & 10 billion \\
\hline Suriname & 2015.03 & 1 billion \\
\hline Switzerland & 2014.07 & 150 billion \\
\hline Thailand & 2011.12 & 70 billion \\
\hline Thailand & 2014.12 & 70 billion \\
\hline Turkey & 2012.02 & 10 billion \\
Ukraine & 2012.06 & 15 billion \\
\hline United Arab Emirates & 2012.01 & 35 billion \\
\hline United Kingdom & 2013.06 & 200 billion \\
\hline Uzbekistan & 2011.04 & 0.7 billion \\
\hline & & \\
\hline
\end{tabular}

Source: Garcia-Herrero and Xia (2013), PBoC, Xinhua, Reuters, Bloomberg, RBA, RBNZ. 
Table 6. BRICS Contingent Reserve Arrangement

\begin{tabular}{lll}
\hline Country & Committed Resources* & Access to CRA Resources** \\
China & \$1 Billion USD & 50 percent \\
Brazil & \$18 Billion USD & 100 percent \\
Russia & \$18 Billion USD & 100 percent \\
India & \$18 Billion USD & 100 percent \\
South Africa & \$5 Billion USD & 200 percent \\
Total & \$100 Billion USD & \\
\hline
\end{tabular}

* As of July 15, 2014.

** Parties can access resources subject to the maximum access limits equal to the specified percentage of each Party's individual commitment.

Source: BRICS Information Centre, University of Toronto (2014). See www.brics.utoronto.ca.

Table 7. CMI Multilateralization Contributions, Purchasing, and Voting

\begin{tabular}{|c|c|c|c|c|}
\hline & \multicolumn{2}{|c|}{ Financial Contribution } & \multirow{2}{*}{$\begin{array}{l}\text { Purchasing } \\
\text { Multiple }\end{array}$} & \multirow{2}{*}{$\begin{array}{l}\text { Total Voting } \\
\text { Power } \\
\text { Percent (\%) }\end{array}$} \\
\hline & USD (billion) & Percent (\%) & & \\
\hline China (Mainland)* & 68.40 & 28.5 & 0.5 & 25.43 \\
\hline Hong Kong, China & 8.40 & 3.5 & 2.5 & 2.98 \\
\hline Japan & 76.80 & 32 & 0.5 & 28.41 \\
\hline Korea & 38.40 & 16 & 1 & 14.77 \\
\hline Plus 3 & 192 & 80 & & 71.59 \\
\hline Indonesia & 9.104 & 3.793 & 2.5 & 4.369 \\
\hline Thailand & 9.104 & 3.793 & 2.5 & 4.369 \\
\hline Malaysia & 9.104 & 3.793 & 2.5 & 4.369 \\
\hline Singapore & 9.104 & 3.793 & 2.5 & 4.369 \\
\hline Philippines & 9.104 & 3.793 & 2.5 & 4.369 \\
\hline Vietnam & 2.00 & 0.833 & 5 & 1.847 \\
\hline Cambodia & 0.24 & 0.1 & 5 & 1.222 \\
\hline Myanmar & 0.12 & 0.05 & 5 & 1.179 \\
\hline Brunei & 0.06 & 0.025 & 5 & 1.158 \\
\hline Lao PDR & 0.06 & 0.025 & 5 & 1.158 \\
\hline ASEAN & 48 & 20 & & 28.41 \\
\hline Total & 240 & 100 & & 100 \\
\hline
\end{tabular}

* China, including Hong Kong, contributes $\$ 76.80$ billion and has $28.41 \%$ of the voting shares.

Source: ASEAN+3 Macroeconomic Research Office (2015). See: www.amro-asia.org. 
Table 8. Reports of RMB Official Reserves by Country

\begin{tabular}{|c|c|c|c|}
\hline Country & Date* & Amount & Type \\
\hline Norway & October, 2006 & up to $\$ 1.5$ bn & onshore \\
\hline Malaysia & September, 2010 & undisclosed & sovereign \\
\hline Hong Kong & October, 2010 & $5-10 \%(\$ 16-\$ 31$ bn) & sovereign \\
\hline Belarus & November, 2010 & undisclosed & onshore \\
\hline Venezuela & August, 2011 & undisclosed & undisclosed \\
\hline Kenya & August, 2011 & undisclosed & undisclosed \\
\hline Chile & September, 2011 & $2.3 \%$ (\$945 mn) & undisclosed \\
\hline Nigeria & September, 2011 & $2-7 \%(\$ 2.3-\$ 4.6$ bn) & offshore \\
\hline Cambodia & October, 2011 & undisclosed & undisclosed \\
\hline Philippines & October, 2011 & undisclosed & undisclosed \\
\hline Russia & October, 2011 & undisclosed & undisclosed \\
\hline Singapore & October, 2011 & up to $\$ 1$ bn & onshore \\
\hline Thailand & November, 2011 & $0.5 \%$ (\$836 mn) & off \& onshore \\
\hline Austria & November, 2011 & undisclosed & onshore \\
\hline Japan & December, 2011 & $\$ 10.3$ bn & sovereign \\
\hline Uruguay & $2012 *$ & $\$ 0.21$ bn & offshore \\
\hline Мacao & March, 2012 & $15.5 \%$ (\$2.5 bn) & off \&onshore \\
\hline Bolivia & May, 2012 & $0.4 \%(\$ 58 \mathrm{mn})$ & offshore \\
\hline Indonesia & July, 2012 & undisclosed & onshore \\
\hline Korea & July, 2012 & $\$ 3.3$ bn & onshore \\
\hline Saudi Arabia & July, 2012 & undisclosed & undisclosed \\
\hline Tanzania & August, 2012 & undisclosed & offshore \\
\hline Pakistan & October, 2012 & undisclosed & onshore \\
\hline Angola & April, 2013 & undisclosed & offshore \\
\hline Australia & April, 2013 & $\$ 1.6$ bn & sovereign \\
\hline Nepal & June, 2013 & undisclosed & onshore \\
\hline South Africa & June, 2013 & $\$ 1.5$ bn & off \& onshore \\
\hline Taiwan & October, 2013 & undisclosed & undisclosed \\
\hline Lithuania & November, 2013 & up to $\$ 100 \mathrm{mn}$ & onshore \\
\hline Namibia & December, 2013 & undisclosed & offshore \\
\hline Ghana & April, 2014 & undisclosed & undisclosed \\
\hline France & April, 2014 & undisclosed & sovereign \\
\hline Switzerland & July, 2014 & up to $\$ 2.5$ bn & onshore \\
\hline Sri Lanka & September, 2014 & undisclosed & onshore \\
\hline Argentina & September, 2014 & $\$ 1.3$ bn & undisclosed \\
\hline United Kingdom & October, 2014 & $\$ 490 \mathrm{mn}$ & offshore \\
\hline Zimbabwe & October, 2014 & undisclosed & undisclosed \\
\hline Hungary & May, 2015 & undisclosed & undisclosed \\
\hline
\end{tabular}




\section{Appendix A: Frankel-Wei Exchange Rate Regressions}

One way of assessing the impact of the renminbi on other countries is to follow Subramanian and Kessler (2013) in estimating so-called Frankel-Wei regressions relating local currency exchange rate movements against a numeraire (say, the Swiss franc) as a function of fluctuations in the renminbi and other major currencies against that same unit:

$$
\begin{aligned}
d \ln \left(\frac{X_{t}}{C H F_{t}}\right) & \\
& =p_{1} * d \ln \left(\frac{U S \$_{t}}{C H F_{t}}\right)+p_{2} * d \ln \left(\frac{R M B_{t}}{C H F_{t}}\right)+p_{3} * d \ln \left(\frac{E U R_{t}}{C H F_{t}}\right)+p_{4} * d \ln \left(\frac{J P Y_{t}}{C H F_{t}}\right) \\
& +\alpha+e_{t}(1)
\end{aligned}
$$

where $d \ln ($ ) denotes the change in the log of currency X, the U.S. dollar, the yuan, the euro, and the Japanese yen, all against the Swiss franc. The coefficients $\left(p_{i}\right)$ describe the co-movement variable for the US dollar, renminbi, euro and Japanese yen. The dominant reference currency is the currency with the highest positive coefficient in (1).

Data are from Reuter's Datastream, here for the period July 2012-July 2015. The results suggest that RMB (and not the dollar, euro or yen) is now the dominant reference currency in 6

\begin{tabular}{|c|c|c|c|c|c|}
\hline & $\begin{array}{l}\text { Renminbi } \\
\text { (RMB) }\end{array}$ & $\begin{array}{l}\begin{array}{l}\text { US Dollar } \\
\text { (USD) }\end{array} \\
\end{array}$ & $\begin{array}{l}\text { Euro } \\
\text { (EUR) }\end{array}$ & $\begin{array}{l}\text { Japanese } \\
\text { Yen (JPY) }\end{array}$ & $\begin{array}{l}\text { Dominant } \\
\text { Reference }\end{array}$ \\
\hline Albania & 0.0065 & 0.0463 & $0.9482 * * *$ & 0.0015 & Euro \\
\hline Argentina & 0.0427 & $1.029 * * *$ & 0.0043 & -0.0588 & US Dollar \\
\hline Bolivia & -0.0024 & 1.0005 & 0.0019 & -0.0004 & US Dollar \\
\hline Bosnia & -0.0017 & $0.0022 * * *$ & 0.9996 & -0.0002 & Euro \\
\hline Brazil & 0.2473 & 0.2671 & $0.3915^{* * *}$ & $0.1168 *$ & Euro \\
\hline Bulgaria & -0.006 & 0.0186 & $0.9936 * * *$ & $(-0.0083) *$ & Euro \\
\hline Chile & 0.0308 & $0.6623 * * *$ & $0.2772 * * *$ & 0.016 & US Dollar \\
\hline Colombia & 0.1425 & $0.534^{*}$ & $0.2094 * * *$ & -0.0164 & US Dollar \\
\hline Croatia & 0.0161 & -0.0366 & 1.016 & 0.0161 & Euro \\
\hline Czech Republic & $(-0.1648)^{* *}$ & 0.0723 & $1.063 * * *$ & -0.001 & Euro \\
\hline Egypt & 0.0682 & $0.9134 * * *$ & -0.0159 & 0.0042 & US Dollar \\
\hline Hong Kong & $0.0235^{* * *}$ & $0.9735 * * *$ & $0.0038 * * *$ & -0.0011 & US Dollar \\
\hline Hungary & 0.046 & -0.0917 & $1.084 * * *$ & -0.0324 & Euro \\
\hline India & $0.4862 * * *$ & $0.3686^{* *}$ & $0.1695 * * *$ & -0.0555 & Renminbi \\
\hline Indonesia & $0.7207 * * *$ & 0.2423 & 0.0305 & -0.031 & Renminbi \\
\hline Israel & 0.1801 & 0.3575 & $0.4653 * * *$ & 0.0037 & Euro \\
\hline Jamaica & $0.088 * *$ & $0.8879 * * *$ & 0.0149 & 0.0049 & US Dollar \\
\hline Jordan & 0.0185 & $0.9937 * * *$ & -0.0064 & $(-0.011)^{* *}$ & US Dollar \\
\hline Lebanon & 0.0077 & $0.9879 * * *$ & -0.0021 & 0.0023 & US Dollar \\
\hline
\end{tabular}
countries in Asia and 2 in Europe. This is out of a total of 41 countries in the sample.

Table A1: Exchange Rate Regressions, July 2012 - July 2015 


\begin{tabular}{|c|c|c|c|c|c|}
\hline Macedonia & 0.1796 & $0.2715^{* *}$ & $0.5129 * * *$ & $0.0509 *$ & Euro \\
\hline Malaysia & $0.902 * * *$ & -0.1012 & $0.1485 * * *$ & -0.0003 & Renminbi \\
\hline Mexico & $0.4352 * * *$ & 0.1396 & $0.446^{* * *}$ & -0.0346 & Euro \\
\hline Morocco & -0.0317 & $0.2693 * * *$ & $0.7598 * * *$ & 0.0034 & Euro \\
\hline Pakistan & 0.00003 & $0.9947 * * *$ & 0.0085 & -0.0097 & US Dollar \\
\hline Paraguay & -0.1258 & $1.105^{* * *}$ & 0.0277 & 0.0058 & US Dollar \\
\hline Peru & $0.2593 * * *$ & $0.6444 * * *$ & $0.0911 * * *$ & 0.0193 & US Dollar \\
\hline Philippines & $0.5031^{* * *}$ & $0.4128 * * *$ & $0.07 * * *$ & 0.0061 & Renminbi \\
\hline Poland & 0.0238 & -0.0869 & $1.1135^{* * *}$ & -0.0144 & Euro \\
\hline Romania & $0.1825^{*}$ & $(-0.1783)^{*}$ & $1.0518 * * *$ & $(-0.03387)^{*}$ & Euro \\
\hline Russia & $0.765 *$ & -0.0544 & $0.2541^{* *}$ & -0.1003 & Renminbi \\
\hline Singapore & $0.3856 * * *$ & $0.1544^{*}$ & $0.2556 * * *$ & $0.1569 * * *$ & Renminbi \\
\hline South Africa & 0.2327 & 0.0324 & $0.5524 * * *$ & 0.1538 & Euro \\
\hline South Korea & $0.8795 * * *$ & -0.0681 & $0.1139 * * *$ & $0.0594 *$ & Renminbi \\
\hline Sri Lanka & 0.0388 & $0.9667 * * *$ & -0.0164 & 0.0002 & US Dollar \\
\hline Taiwan & $0.452 * * *$ & $0.4803 * * *$ & $0.0353^{*}$ & 0.0077 & US Dollar \\
\hline Thailand & 0.1254 & 0.1054 & 0.2306 & 0.022 & Euro \\
\hline Tunisia & -0.1097 & $0.4214^{* * *}$ & $0.6522 * * *$ & $0.0312^{* *}$ & Euro \\
\hline Turkey & 0.1091 & 0.2016 & $0.4242 * * *$ & -0.0083 & Euro \\
\hline Ukraine & 0.6096 & 0.1275 & 0.2818 & -0.0225 & Renminbi \\
\hline Uruguay & -0.1077 & $1.082 * * *$ & $0.0985 * *$ & 0.0052 & US Dollar \\
\hline Vietnam & -0.0359 & $1.042 * * *$ & 0.0002 & -0.0048 & US Dollar \\
\hline
\end{tabular}

${ }^{* * *} \mathrm{p}<0.01,{ }^{* *} \mathrm{p}<0.05,{ }^{*} \mathrm{p}<0.1$.

The renminbi is a statistically significant determinant of the exchange rate for 14 of the countries considered, even after controlling for the impact of the dollar, with which the renminbi is correlated. $^{33}$

The effect is also large economically in a number of cases. Table A2 tabulates the number of cases where the renminbi is the currency with the largest impact. The geographical pattern is suggestive in that the renminbi tends to have its largest effect in Asia, whereas the euro has its largest effect in Europe, while the influence of the dollar is distributed globally.

\footnotetext{
${ }^{33}$ A caveat is that it is still possible that, owing to multicollinearity between the renminbi and the dollar, the impact of the latter is being spuriously attributed to the former.
} 
Table A2. Dominant Reference Currency by Region (2012-2015)

\begin{tabular}{llll}
\hline & RMB & USD & Euro \\
\hline Asia & 6 & 5 & 1 \\
Europe & 2 & 0 & 10 \\
Middle East and Africa & 0 & 3 & 4 \\
North America & 0 & 1 & 1 \\
South America & 0 & 7 & 1 \\
& 8 & 16 & 17 \\
\hline
\end{tabular}

Subramanian and Kessler then relate the coefficient on the renminbi/Swiss franc exchange rate in the preceding equation to bilateral trade with China, the similarity of inflation rates, and common financial shocks:

$p_{\text {Country } i}^{R M B}=$

$\alpha *$ ShTrade $_{\text {Country } i}^{\text {China }}+\beta *$ CommonInflation $_{\text {Country } i}^{\text {China }}+\gamma *$ CommonFinancialShocks $_{\text {Country } i}^{\text {China }}+e_{i}$

Common inflation shocks are measured as the correlation between a country's monthly inflation rate and that of China during the period January 2012-December 2014, while common financial shocks are then taken as the correlation between a country's reference stock market index daily returns and the Shanghai Stock Exchange A Share Index daily returns over the July 2012-October 2014 period. The data correspond to the sample in Subramanian and Kessler (2013). See below for a detailed list of the stock market indices. Both the inflation figures and the stock index return figures are logged. The share of trade is measured as the proportion of a country's imports from China relative to the imports from the rest of the world. This figure is taken as the average import ratios for the 2012-2013 period.

Li near regressi on

$\begin{array}{llr}\text { Number of obs } & = & 35 \\ \text { F( 3, 31) } & = & 3.48 \\ \text { Prob }>\text { F } & = & 0.0275 \\ \text { R-squar ed } & = & 0.2678 \\ \text { Root MEE } & = & .2553\end{array}$

\begin{tabular}{|c|c|c|c|c|c|c|}
\hline$r \mathrm{mb}$ & Coef. & $\begin{array}{l}\text { Robust } \\
\text { St d. Err. }\end{array}$ & $\mathrm{t}$ & $P>1 t \mid$ & [ 95\% Conf . & I nt erval ] \\
\hline $\begin{array}{r}\text { fi nanci al _-y } \\
\text { i nf I at īon } \\
\text { i mport share } \\
\text { _cons }\end{array}$ & $\begin{array}{r}1.694931 \\
-.2414102 \\
-1.310916 \\
.1651439\end{array}$ & $\begin{array}{l}5871824 \\
.1520255 \\
.8483331 \\
.0924021\end{array}$ & $\begin{array}{r}2.89 \\
-1.59 \\
-1.55 \\
1.79\end{array}$ & $\begin{array}{l}0.007 \\
0.122 \\
0.132 \\
0.084\end{array}$ & $\begin{array}{r}.4973646 \\
-.5514683 \\
-3.041103 \\
-.0233115\end{array}$ & $\begin{array}{l}2.892497 \\
.0686479 \\
.4192707 \\
.3535993\end{array}$ \\
\hline
\end{tabular}

The coefficient of a country's financial shock is positive and statistically significant (1.69). Thus, we observe a larger renminbi co-movement from a higher correlation for a country's financial market with China, controlling for inflation and trade. Evidently, the coefficients for inflation shocks and trade shares, although negative, do not seem to affect the renminbi co-movement for the sample countries' exchange rates. 
Data Source: Data for the equity indices in daily format are from Reuters Datastream. Inflation shocks are calculated using data from the International Monetary Fund's International Financial Statistics (IFS) database on consumer price index to evaluate the correlation between the CPI inflation rate in logged form. Bilateral trade data are from UN Comtrade, computing country X's import with China as a fraction of trade it does with the rest of the world - all from the import side.

Following Subramanian and Kessler (2013), the financial market data are:

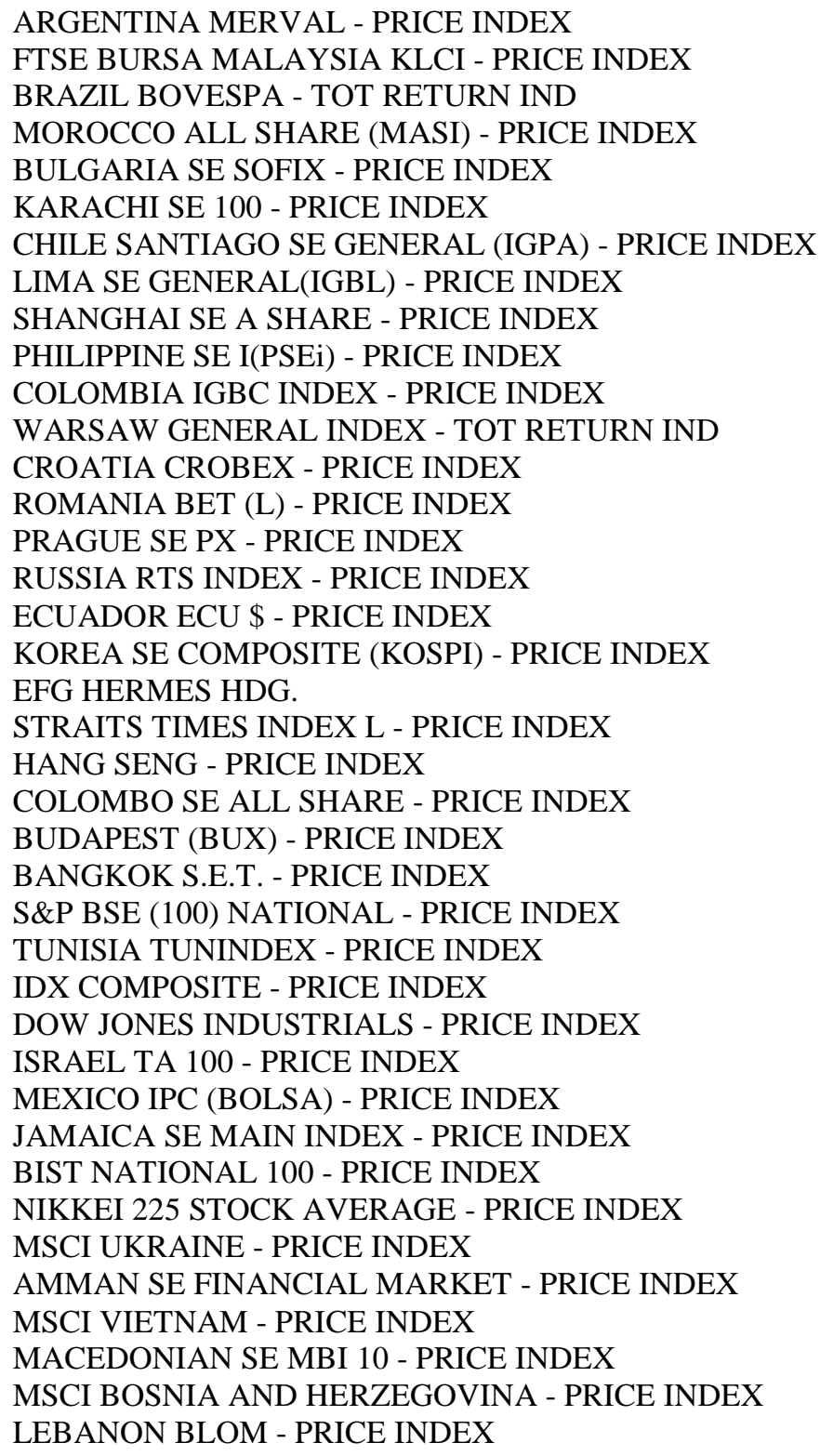




\section{Appendix B. Determinants of China's Bilateral Swap Arrangements}

In this appendix we extend the analysis of Garcia-Herrero and Xia (2013), asking whether Asian countries are more likely than others to be on the receiving end of PBOC bilateral swap arrangements. We use an updated list of swap agreements and add to their specification a dummy variable for Asian countries to test whether Asian countries are more likely than countries in other parts of the world to receive swap lines from the PBOC, ceteris paribus.

The annual data here cover the period 2005-2013 and all available (up to 166) countries. We estimate our equations by probit (where the dependent variable is a zero/one indicator of whether a swap is in place), ordered probit where we distinguish no swaps, small swaps and large swaps (small and large being below and above 50 billion yuan), and tobit where we use as the dependent variable the size of the swap in yuan.

The results uniformly show that countries in Asia are no more likely than countries elsewhere to have PBOC swaps, controlling for their economic characteristics and links with China. A variety of other variables tend to increase the likelihood of a swap: that a country is an important export destination for China, that there exist bilateral or multilateral free trade agreements and that the country is geographically close to China, where this last variable is likely to capture other links between the partners.

In addition, a PBOC swap is more likely when a country has a relatively closed capital account, limiting the ability of market participants to readily access foreign-currencydenominated liquidity.

But once we control for these other variables, the Asia dummy or fixed effect adds no explanatory power.

Adding dummy variables or fixed effects for other regions increases the significance of the Asia dummy, but only slightly. 


\section{Table B1. Determinants of Bilateral Swap Arrangements}

Probit Regressions

(1)

Log GDP (US\$, real)

Share of Recipient Exports to China

FTA with China

Share of Chinese FDI to Recipient

Open Capital Account

Inflation

Past Default

Distance from Beijing

Asian Country[1]

Constant

\begin{tabular}{ll}
$0.271 * * *$ & $.270 * * *$ \\
$(3.74)$ & $(3.88)$ \\
$0.035^{* * *}$ & $0.033^{* * *}$ \\
$(3.36)$ & $(3.27)$ \\
$0.764 *$ & $0.647^{*}$ \\
$(1.88)$ & $(1.69)$ \\
-0.004 & -0.0003 \\
$(-0.21)$ & $(-0.02)$ \\
$-0.201 * *$ & $-0.209 * *$ \\
$(-2.10)$ & $(-2.24)$ \\
-0.015 & -0.009 \\
$(-0.54)$ & $(-0.35)$ \\
0.519 & 0.412 \\
$(1.35)$ & $(1.15)$ \\
$-0.062 *$ & \\
$(-1.69)$ & \\
-0.453 & 0.017 \\
$(-0.87)$ & $(0.05)$ \\
$-8.165 * * *$ & $-8.698 * * *$ \\
$(-4.32)$ & $(-4.84)$ \\
\hline 472 & 472 \\
0.271 & 0.255 \\
&
\end{tabular}

Number of Obs

Pseudo R2

(2)

$270 * * *$

(3.88)

(3.27)

$0.647 *$

$-0.0003$

.02)

$(-2.24)$

0.412

$(1.15)$

0.017

$-8.698 * * *$

*** $\mathrm{p}<0.01, * * \mathrm{p}<0.05, * \mathrm{p}<0.1$.

[1] Asian country dummy equals 1 for East Asian and South East Asian countries, including Hong Kong SAR. 
Table B2. Determinates of Bilateral Swap Arrangements, Alternative Estimators

Ordered Probit and Tobit Regressions

\begin{tabular}{|c|c|c|c|c|}
\hline & & & (3) & \\
\hline & Ordered Probit & Ordered Probit & Tobit & Tobit \\
\hline Log GDP (US\$, real) & $\begin{array}{l}0.291 * * * \\
(4.00)\end{array}$ & $\begin{array}{l}0.291 * * * \\
(4.10)\end{array}$ & $\begin{array}{l}39.899 * * * \\
(3.63)\end{array}$ & $\begin{array}{l}39.216 * * * \\
(3.70)\end{array}$ \\
\hline Distance from Beijing & $\begin{array}{l}-0.037 \\
(-1.06)\end{array}$ & & $\begin{array}{l}-4.41 \\
(-0.95)\end{array}$ & \\
\hline $\begin{array}{l}\text { Share of Recipient } \\
\text { Exports to China }\end{array}$ & $\begin{array}{l}0.032^{* * *} \\
(3.19)\end{array}$ & $\begin{array}{l}0.031^{* *} \\
(3.16)\end{array}$ & $\begin{array}{l}4.306^{* *} \\
(2.95)\end{array}$ & $\begin{array}{l}4.118^{* *} \\
(2.95)\end{array}$ \\
\hline FTA with China & $\begin{array}{l}0.700 * \\
(1.81)\end{array}$ & $\begin{array}{l}0.636^{*} \\
(1.71)\end{array}$ & $\begin{array}{l}84.667 \\
(1.63)\end{array}$ & $\begin{array}{l}75.541 \\
(1.53)\end{array}$ \\
\hline $\begin{array}{l}\text { Share of Chinese FDI } \\
\text { to Recipient }\end{array}$ & $\begin{array}{l}0.002 \\
(0.09)\end{array}$ & $\begin{array}{l}0.003 \\
(0.20)\end{array}$ & $\begin{array}{l}0.617 \\
(0.30)\end{array}$ & $\begin{array}{l}0.853 \\
(0.43)\end{array}$ \\
\hline Open Capital Account & $\begin{array}{l}-0.214^{* *} \\
-(2.25)\end{array}$ & $\begin{array}{l}-0.22 * * \\
(-2.35)\end{array}$ & $\begin{array}{l}-25.767 * * \\
(-2.01)\end{array}$ & $\begin{array}{l}-25.97 * * \\
(-2.07)\end{array}$ \\
\hline Inflation & $\begin{array}{l}-0.015 \\
(-0.56)\end{array}$ & $\begin{array}{l}-0.012 \\
(-0.46)\end{array}$ & $\begin{array}{c}-1.743 \\
(-1.50)\end{array}$ & $\begin{array}{l}-1.376 \\
(-0.41)\end{array}$ \\
\hline Past Default & $\begin{array}{l}0.403 \\
(1.07)\end{array}$ & $\begin{array}{l}0.353 \\
(0.98)\end{array}$ & $\begin{array}{l}43.956 \\
(1.68)\end{array}$ & $\begin{array}{l}37.342 \\
(0.78)\end{array}$ \\
\hline Asian Countries & $\begin{array}{l}-0.124 \\
(-0.25)\end{array}$ & $\begin{array}{l}0.154 \\
(0.37)\end{array}$ & $\begin{array}{r}-20.972 \\
(-0.33)\end{array}$ & $\begin{array}{l}12.436 \\
(0.24)\end{array}$ \\
\hline Constant & & & $\begin{array}{l}-1211.152^{* * *} \\
(-3.98)\end{array}$ & $\begin{array}{l}-1229.977 * * * \\
(-4.12)\end{array}$ \\
\hline Number of Obs & 472 & 472 & 472 & 472 \\
\hline Pseudo R2 & 0.246 & 0.241 & 0.127 & 0.124 \\
\hline
\end{tabular}


Table B3. Additional Determinants of Bilateral Swap Arrangements

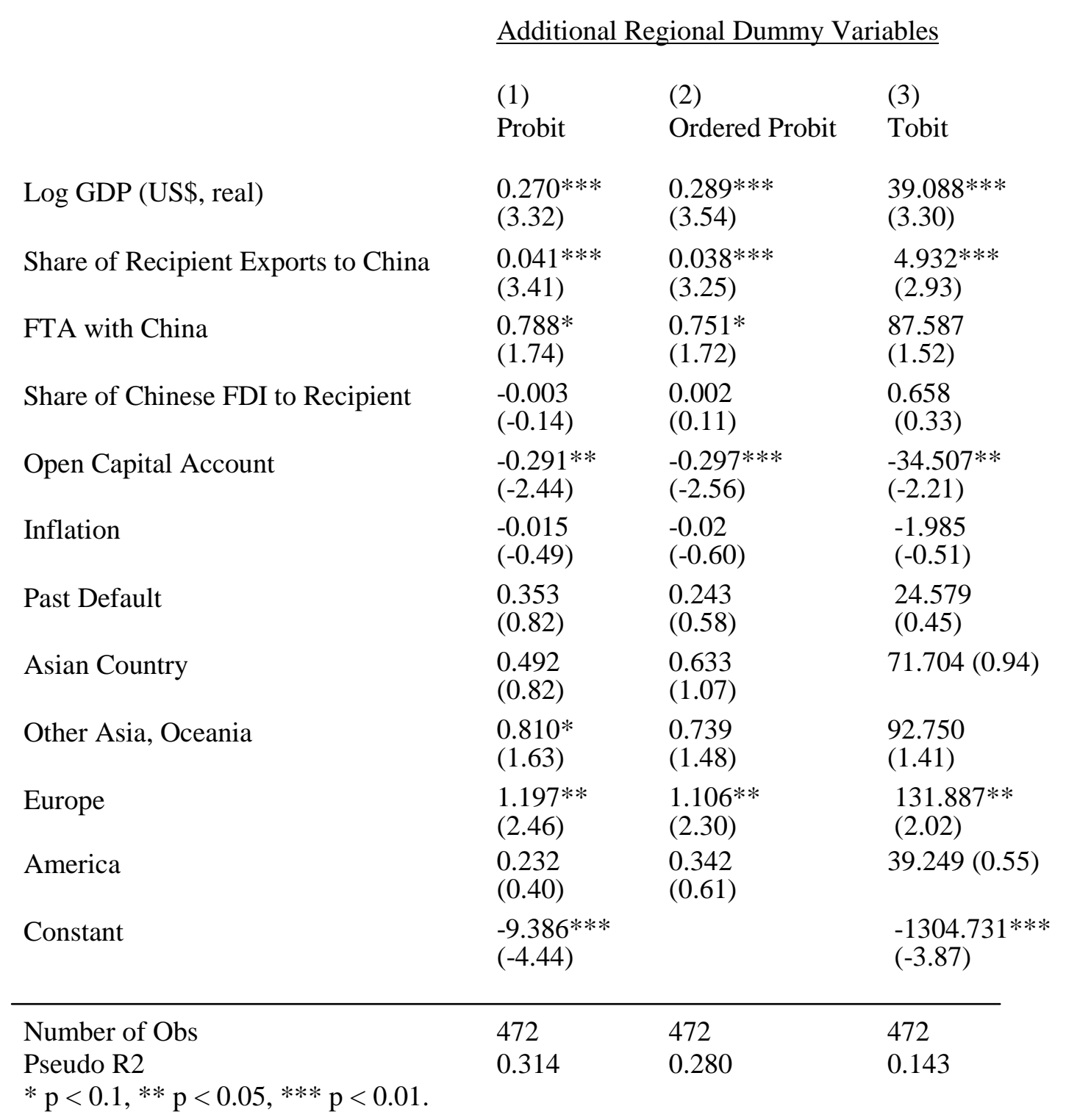

Data Source: GDP data is from the World Bank. Distance from Beijing data is from Kristian Skrede Gleditsch, accessed through http://privatewww.essex.ac.uk/ ksg/data-5.html and calculated using Google Maps. Export data is from UN Comtrade database and The Observatory of Economic Complexity. Chinese overseas FDI data is from CEIC. Capital account openness uses the Chin-Ito index, accessed through http://web.pdx.edu/ ito/Chinn-Ito_website.htm. Default data collected from Moody's (The Moody's “Special Comment: Sovereign Default and Recovery Rates, 1983-2010”). Inflation data is from the World Bank and International Monetary Fund. Swap arrangements data is from Garcia-Herrero and Xia (2013) and People's Bank of China. Free trade agreements are accessed online through the Ministry of Commerce, the People’s Republic of China (http://fta.mofcom.gov.cn/english/index.shtml). 


\section{References}

Abe, Kazutomo and John Wilson (2009), "Weathering the Storm: Investing in Port Infrastructure to Lower Transport Costs in East Asia,” World Bank Policy Research Working Paper no.4911, Washington, D.C.: World Bank.

Asian Infrastructure Investment Bank(2015), “Prospective Founding Members.” Retrieved 30 October , from http://www.aiib.org/html/pagemembers/

Anderson, James and Eric van Wincoop (2004), “Trade Costs,” Journal of Economic Literature 42, pp.691-751.

ASEAN+3 Macroeconomic Research Office (2015), "Contributions, Purchasing Multiple, Maximum Swap Amount.” Retrieved July 22 2015, from http://www.amro-asia.org/aboutamro/history/country-representation/

Bergsten, C. Fred (1975), The Dilemmas of the Dollar, New York: New York University Press.

Brainard, S.L. (1997), “An Empirical Assessment of the Proximity-Concentration Trade-off Between Multinational Sales and Trade,” American Economic Review 87, pp.520-544.

BRICS Information Centre, University of Toronto (2014), "Treaty for the Establishment of a BRICS Contingent Reserve Arrangement." Retrieved October 30 2015, from http://www.brics.utoronto.ca/docs/140715-treaty.html.

Chey Hyoung-kyu (2012), “Can the Renminbi Rise as a Global Currency? The Political Economy of Currency Internationalization.” GRIPS Discussion Paper 11-20.

Ministry of Commerce, China (2015), “China FTA Network.” Retrieved July 22, from http://fta.mofcom.gov.cn/english/index.shtml.

Chitu, Livia, Barry Eichengreen and Arnaud Mehl (2013), "When did the Dollar Overtake Sterling as the Leading International Currency? Evidence from the Bond Market," Journal of Development Economics 111, pp.225-245.

Chitu, Livia, Barry Eichengreen and Arnaud Mehl (2014), "History, Gravity and International Finance,” Journal of International Money and Finance 46, pp.104-129.

Di Giovanni, Julian (2002), "What Drives Capital Flows? The Case of Cross-Border M\&A Activity and Financial Deepening," CIDER Working Paper no.C02-122, Berkeley: Center for International and Development Economic Research, University of California, Berkeley.

Eichengreen, Barry (2014), "International Currencies Past, Present and Future: Two Views from Economic History,” Working Paper no.2014-31, Seoul: Bank of Korea.

Eichengreen, Barry and Marc Flandreau (1996), "Blocs, Zones and Bands: International Monetary History in Light of Recent Theoretical Developments," Scottish Journal of Economics 43, pp.398-418. 
Eichengreen, Barry and Marc Flandreau (2009), “The Rise and Fall of the Dollar (or When Did the Dollar Replace Sterling as the Leading International Currency?), European Review of Economic History 13, pp.377-411.

Eichengreen, Barry and Marc Flandreau (2011), “The Federal Reserve, the Bank of England, and the Rise of the Dollar as an International Currency, 1914-1939,” Open Economies Review 23, pp.53-87.

Farrell, Joseph and Paul Klemperer (2007), "Coordination and Lock-In: Competition with Switching Costs and Network Effects," in Mark Armstrong and Robert Porter (eds), Handbook of Industrial Organization, Volume 3, Amsterdam: North-Holland, pp.1967-2072.

Feenstra, Robert (1998), "Integration of Trade and Disintegration of Production in the Global Economy,” Journal of Economic Perspectives 12, pp.31-50.

Frankel, Jeffrey and Shangjin Wei (2008), "Estimation of De Facto Exchange Rate Regimes: Synthesis of the Techniques for Inferring Flexibility and Basket Weights,” IMF Staff Papers 55, pp.384-416.

Gao, Shen (2009), “The Predictive Capacity of the Gravity Model of Trade on Foreign Direct Investment,” unpublished manuscript, Uppsala University.

Garcia-Herrero, Alicia and Le Xia (2013), “China’s RMB Bilateral Swap Agreements: What Explains the Choice of Countries?” Institute for Economies in Transition Discussion Paper no.12/2013, Helsinki: Bank of Finland.

Gehrig, Thomas (2000), “Cities and the Geography of Financial Centers,” in Jean-Marie Hurot and Jacques-Francois Thisse eds, Economics of Cities: Theoretical Perspectives, Cambridge: Cambridge University Press, pp.414-446.

Goldberg, Linda and Cedric Tille (2005), “Vehicle Currency Use in International Trade,” Staff Report no.200, New York: Federal Reserve Bank of New York.

Han Minchun and Yuan Xiulin(2006), "RMB Regionalization: From Point of View of Trade [基 于贸易视角的人民币'区域化'的微观经济分析]," Journal of International Trade Issues [国际 贸易问题，issue 9.

Hatzvi, Eden, Will Nixon and Michelle Wright (2014), “Offshore Renminbi Market and Australia.” RBA Bulletin Quarter 4 (December).

Helleiner, Eric and Jonathan Kirshner eds. (2014), The Great Wall of Money: Power and Politics in China's International Monetary Relations, Ithaca: Cornell University Press.

Huo Weidong and Yang Biqin( 2013), "The Strategic Speeding-up of RMB Regionalization in FTA: An Empirical Study based on CAFTA [自由贸易区战略助推人民币区域化]."Journal of International Trade[ 国际贸易问题], issue 2 .

Kawai, Masahiro and Victor Pontines (2014), “The Renminbi and Exchange Rate Regimes in East Asia.” ADBI Working Paper no. 484 (May). 
Krugman, Paul (1980), "Vehicle Currencies and the Structure of International Exchange," Journal of Money, Credit and Banking 12, pp.513-526.

Krugman, Paul (1984), "The International Role of the Dollar: Theory and Prospect,” in John Bilson and Richard Marston (eds), Exchange Rate Theory and Practice, Chicago: University of Chicago Press, pp.261-278.

Li Xiao, Li Junjiu and Ding Yibing (2004) , "On the 'Asianization' of Renminbi [论人民币的 亚洲化],"The Journal of World Economy [世界经济], issue 2.

Liao, Steven and Daniel McDowell (2015), "Redback Rising: China's Bilateral Swap Agreements and Renminbi Internationalization," unpublished manuscript, University of Virginia and Syracuse University.

Limao, Nuno and Anthony Venables (1999), "Infrastructure, Geographical Disadvantage, and Transport Costs,” Policy Research Working Paper no.2257, Washington, D.C.: The World Bank.

Lindert, Peter (1969), “Key Currencies and Gold, 1900-1913,” Princeton Studies in International Finance no.24, International Finance Section, Princeton University, Department of Economics.

Matsuyama, Kiminori, Nobuhiro Kiyotaki and Akihiko Matsui (1993), "Toward a Theory of International Currency,” Review of Economic Studies 60, pp.283-307.

McKinnon, Ronald (1979), Money in International Exchange: The Convertible Currency System, New York: Oxford University Press.

Offshore Group (2013), "Mexico vs China: By the Numbers,” Tuscon, AZ: Offshore Group, http://offshoregroup.com/2013/10/25/mexico-vs-china-by-the-numbers/.

Paniagua, Jordi (2011), “FDI Gravity Equation: Models, Estimations and Zeros,” unpublished manuscript, Catholic University of Valencia.

Portes, Richard and Helene Rey (2000), “The Determinants of Cross-Border Equity Flows: The Geography of Information,” CEPR Discussion Paper no.2225, London: Centre for Economic Policy Research.

Portes, Richard, Helene Rey and Yonghyup Oh (2001), "Information and Capital Flows: The Determinants of Transactions in Financial Assets," European Economic Review 45, pp.783-796.

Posen, Adam (2009), “Geopolitical Limits to the Euro's Global Role,” in Jean Pisani-Ferry and Adam Posen (eds), The Euro at Ten: The Next Global Currency? Brussels and Washington, D.C.: Bruegel and Peterson Institute of International Economics.

Prasad, Eswar (2014), The Dollar Trap: How the US Dollar Tightened its Grip on Global Finance, Princeton: Princeton University Press.

Rey, Helene (2001), “International Trade and Currency Exchange,” Review of Economic Studies 68, pp.443-464. 
Standard Chartered (2014), “Global Trade Unbundled,” Standard Chartered Global Research, Hong Kong: Standard Chartered.

Subramanian, Arvind and Martin Kessler (2013), “The Renminbi Bloc is Here: Asia Down and the Rest of the World to Go,” Working Paper no. WP 12-19, Washington, D.C.: Peterson Institute of International Economics (August).

Ugolini, Stefano (2012), "Foreign Exchange Reserve Management in the $19^{\text {th }}$ Century: The National Bank of Belgium in the 1850s,” Norges Bank Working Paper no.2011/07.

Weir, Geoffrey (2015), “Offshore RMB Centres: Some Observations of Relevance to Sydney,” unpublished manuscript.

Whalley, John and Chunding Li (2014), “China’s Regional and Bilateral Trade Agreements,” VoxEU (5 March). 